\title{
Controlling the longwall coal mining process at a variable level of methane hazard
}

\author{
Stanistaw TRENCZEK ${ }^{1}$, Aleksander LUTYNSSKI ${ }^{2}$, Artur DYLONG \\ and Piotr DOBRZANIECKI *
}

Authors' affiliations and addresses: ${ }^{1}$ KOMAG Institute of Mining Technology, Pszczyńska 37, 44-101 Gliwice, Poland e-mail: strenczek@komag.eu

${ }^{2}$ KOMAG Institute of Mining Technology, Pszczyńska 37, 44-101 Gliwice, Poland e-mail: alutynski@komag.eu

${ }^{3}$ Silesian University of Technology, Faculty of Mining, Safety Engineering and Industrial Automation, Department of Electrical Engineering and Industrial Automation, Akademicka 2, 44-100 Gliwice, Poland e-mail: Artur.Dylong@polsl.pl

${ }^{4}$ KOMAG Institute of Mining Technology, Pszczyńska 37, 44-101 Gliwice, Poland e-mail: pdobrzaniecki@komag.eu

*Correspondence:

Piotr Dobrzaniecki, KOMAG Institute of Mining Technology, Pszczyńska 37, 44-101

Gliwice, Poland

tel: 322374650

e-mail: pdobrzaniecki@komag.eu

How to cite this article:

Trenczek, S., Lutyński, A., Dylong, A. and Dobrzaniecki, P. (2020). Controlling the longwall coal mining process at a variable level of methane hazard. Acta Montanistica Slovaca, Volume 25 (2), 159-169

DOI:

https://doi.org/10.46544/AMS.v25i2.3

\begin{abstract}
The systems for monitoring the mine atmosphere, especially in the longwall panels, have been used for many years. Thanks to their use, it was possible to reduce the number of hazardous events (accidents). Until now, the attention was paid primarily on securing the mine personnel as the most important aspect of the methane explosion hazard. Recent years show that the number of accidents in Poland decreased to several cases per year. Such an event can cause a risk of damage. In order to further reduce the number of hazardous events, the existing solutions will not be enough, so a new approach to monitoring and using the methane concentration prediction methods in longwall panels is necessary to be applied.

The reasons for changes in methane hazard level at the coalmine longwall faces are discussed at the beginning. Then, the methods for controlling the longwall shearer's operation depending on methane hazard level are presented. Dangerous events caused by the sudden outflow of methane into the longwall panel were recalled. In the further part, an additional subsystem for monitoring the methane concentration in the longwall panel in the context of controlling the operation of the longwall shearer and the run-of-mine transportation in the longwall area is described. Finally, the importance of the new way of controlling the mining process and run-of-mine transportation for work safety and mining efficiency was emphasized.
\end{abstract}

\section{Keywords}

hard coal mining, methane hazard, controlling the longwall shearer's operation, monitoring. 


\section{Introduction and base information}

As it is known, methane in the rock mass occurs as:

- adsorbed methane, physically and chemically bonded to the carbonaceous substance,

- free methane, in pores and crevices of waste rock and coal seams.

The amount of methane flowing from the rock mass into the longwall area is determined by many factors, but the thickness and permeability of the overburden resting on the carbonaceous layer are important - the thicker and less permeable overburden, the higher methane content of the deposit underneath.

In methane seams, methane flows into the longwall face in two ways (Szlązak et al., 2005). It may be a direct inflow - i.e. from the coal of the mined seam in each phase of the mining process (mainly, during mining and transportation of excavated material), and from the exposed solid coal of a longwall panel in the zone of operating pressure. It can also be an indirect inflow - in the case of using a block caving method in the longwall panel.

Post-mining gob in an operating mine includes large rock mass volumes to which permanent methane emissions occur. In addition, they are a reservoir of free methane and create their migration pathways. There are also gaseous-geological dynamic phenomena which, as a result of rock mass burst, cause the inflow of large volume of high concentrated methane to the workings in the area of the longwall panel (Karacan et al., 2007; Karacan et al., 2010). Moreover, gaseous dynamic phenomena cause the inflow of relatively small volumes of methane with often explosive concentration.

Each of the above inflows is troublesome. In the case of methane inflow with a lower concentration than the lower explosion limit $\left(\mathrm{CH}_{4}\right.$ below $\left.4.5 \%\right)$ requires stopping the operation of cutting machines and transportation equipment, while in the case of an explosive mixture (methane in concentration 4.5-15\%, oxygen in a concentration above 16\%), methane can ignite and even explode if at the same time (one of many) initials occur (Mathatho et al., 2019; Trenczek, 2015). Therefore, it is extremely important to recognize the area of the longwall panel and its neighbourhood in terms of the possibility of methane inflow to the longwall and longwall workings.

\section{The standard method for controlling the methane concentrations in the longwall area}

Regardless of the recognized conditions in which the exploitation of the coal seam is planned and realized, the legal regulations of the Polish mining industry (Mathatho et al., 2019) require monitoring the methane concentration in a specified way depending on how the longwall is ventilated.

Typical location of methane sensors (methane meters) in the longwall area, in accordance with the regulations (Dz.U. nr 1118, 2017), with the most common ventilation methods, are presented in Figures 1-3.

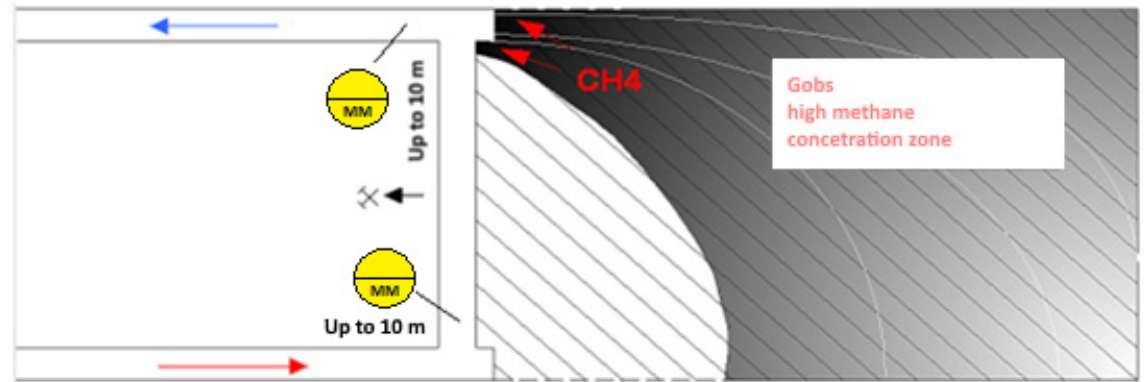

Fig. 1. Example of a typical arrangement of methane meters together with the model of methane distribution in gob at $U$ ventilation method (developed on the basis of (Dziurzyński, 2009))

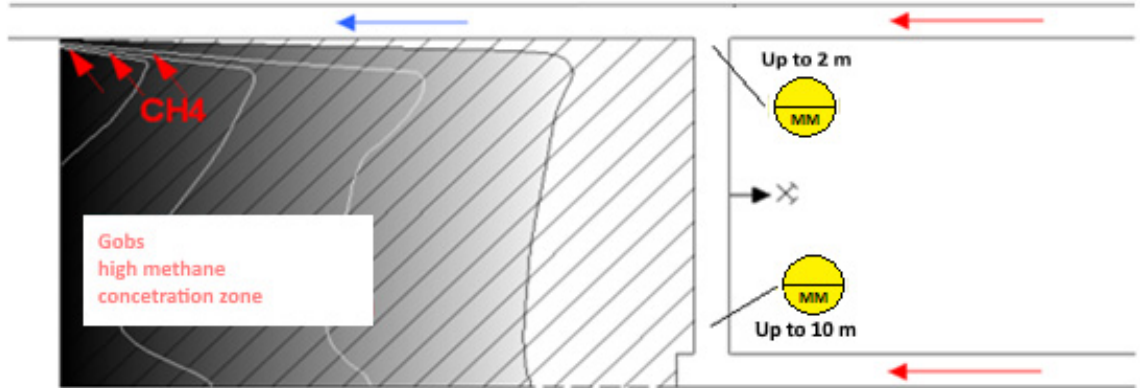

Fig. 2. Example of a typical arrangement of methane meters together with the model of methane distribution in gob at $Y$ ventilation method with a refreshment of outflow air (developed on the basis of (Dziurzyński, 2009) 


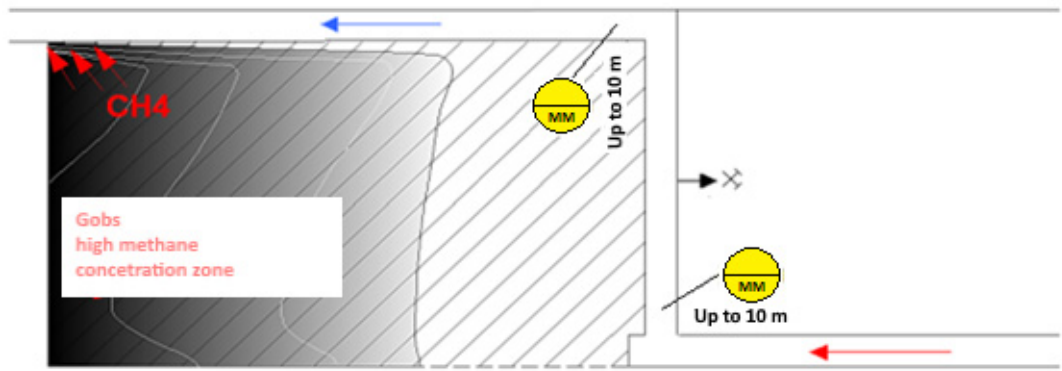

Fig. 3. Example of a typical arrangement of methane meters together with the model of methane distribution in gob at $Z$ ventilation method (developed on the basis of (Dziurzyński, 2009)

Cutting off the power supply of electrical machines and devices operating in the area is the reaction for the signal from the methane sensor informing about exceedance of the threshold concentration (Mathatho et al., 2019). This allows, as already mentioned, to protect the region against the possibility of the appearance of an ignition initial from the operating machines and equipment, and at the same time causes a break in coal mining, what results in economic losses.

However, this method of monitoring is insufficient both to completely eliminate methane ignition from the operation of machines and equipment, and to ensure rational, optimally economical coal mining. In the case of sudden methane inflow - for example, from roof fall due to a dynamic change in atmospheric pressure (Zhu et al., 2007), or disturbances in airflow, or due to gaseous geodynamic phenomena (Lutyński, 2010), - locally, outside the place of control by a methane meter - an explosive mixture of small volume can appear. As a result, methane can be ignited from the operating longwall shearers or roadheaders - in the years 2005-2019 in the Polish mining industry, there were 21 such ignitions (Wu et al., 2005), (Trenczek et al., 2019). In turn, the inability to respond to a gradual increase in methane concentration due to its release from the mined seam, for example, by slowing down the mining process, causes the electricity to be turned off and thus production downtime.

The above drawbacks of the method used to monitor the longwall area can be eliminated by improving the effectiveness of the monitoring and switching off the system using the additional longwall methane-metric system (Dylong, 2019).

\section{Current methods for controlling the longwall shearer operation}

Longwall shearer, due to its complicated design, has few control systems connected to the central controller.

Main shearer modules are the following:

- central controller - responsible for the control of the shearer systems,

- power supply control module - responsible, for example, for the control of insulation condition,

- hydraulic systems and driving systems control module - responsible for pressure control in a hydraulic system, control of voltage and current in electric motors,

- $\quad$ system for controlling the electro valves of the hydraulic installation - responsible for controlling the shearer's moving parts,

- $\quad$ radio control system - ensuring safe work by use of the remote controller,

- surface system for visualization and monitoring - control of the current condition of the shearer, recording of critical parameters.

The simplified diagram of the shearer control system, presented in Fig. 4, can differ among different manufacturers

None of the currently used longwall shearers uses information from automatic methanometry to control the shearer's output (Sevitel Sp. z o.o., 2012; Dylong et al., 2013). In many cases, based on operational experience, users themselves take the manual measurements of methane concentration in front of the shearer and based on them change the mining rate.

Commonly used automatic methanometry is applied to stop the longwall system operation - by cutting off power supply - when $\mathrm{CH}_{4}$ exceeds $2 \%$ in the air, controlled by a methane meter installed at the longwall outlet. This is to prevent against ignition/explosion of methane in a result of the operation of mechanical or/and electrical equipment in the longwall area if the methane concentration exceeded $4.5 \%$. It means that the methanometry system is a blocking system and not a control system. 


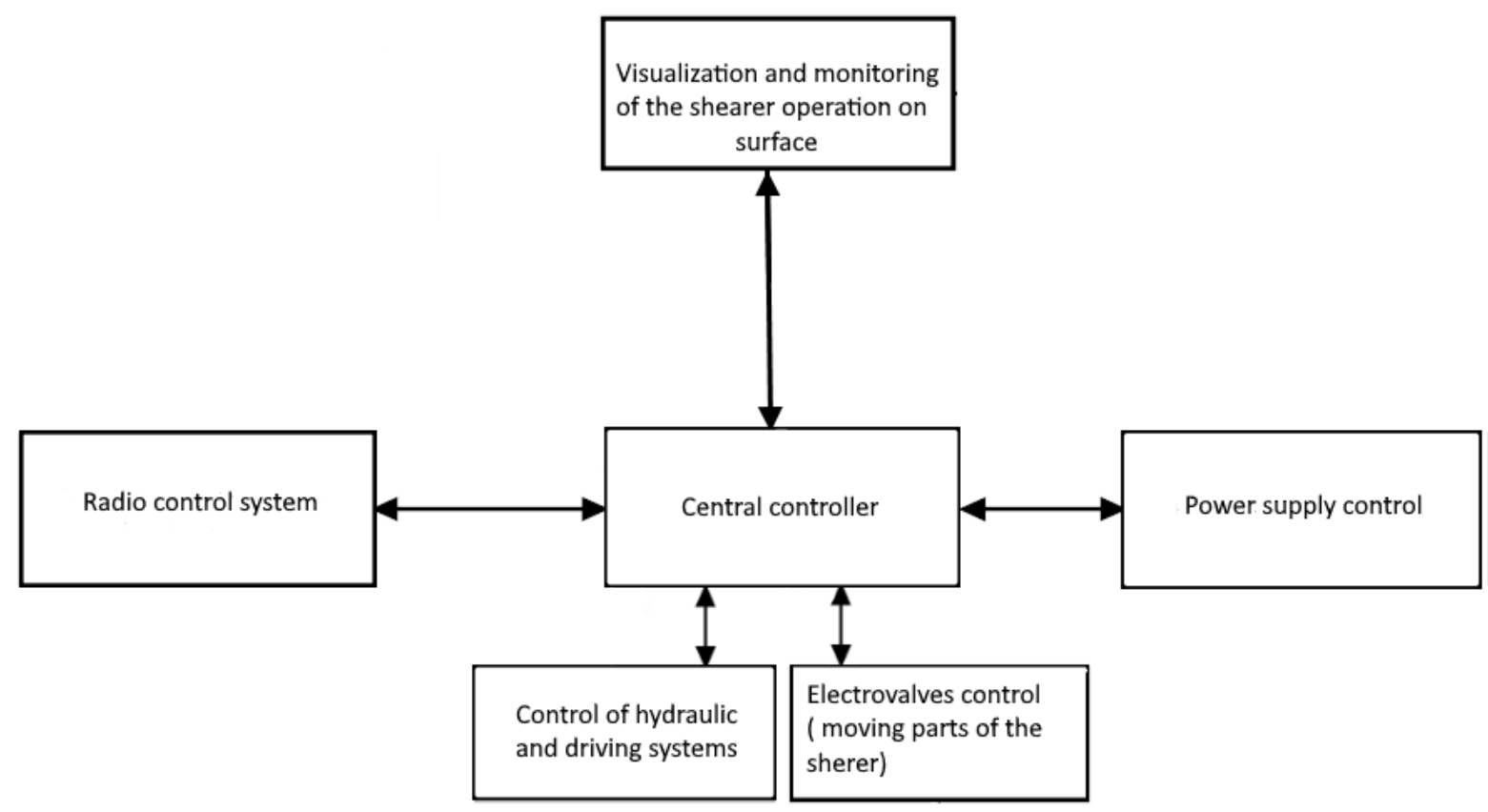

Fig. 4. Simplified block diagram of the shearer control system

\section{Methane hazard monitoring system}

The element that distinguishes the methanometric systems used worldwide is the method of the system power supply.

Automatic methanometric system in Poland was based on the OLDHAM CTT-63/40U type of methanometric system imported from France, for which a license was purchased in later years. It allows using the stationary methane meters for measuring low (up to 5\%) and high (up to 100\%) methane concentrations as well as using the stationary sensors for measuring air flowrate. This system uses a central power supply, which means that subsequent new systems emerging in Poland were also based on the central power supply, requiring a fixed infrastructure. Due to the multi-core cables, their installation in the mine shaft and the roadways must be stable and durable.

In the case of foreign systems, local power supply with a buffer in the form of a battery pack is used. Depending on the regulations being in force in each country, the systems are equipped with batteries that support the operation of devices from 4 to 16 hours. This causes some difficulties, however, compared to the costs associated with the construction of cable installations (cable laying on the surface, in the shaft and mine underground) is accepted. An additional benefit of using the local power supply is the ability to quick movement of the system to any place in the mine.

Regardless of the power source (supplying method), each system - both used in Poland and abroad - has similar functionality. The systems inform about threats in the place of their occurrence and the dispatcher room; then they turn off electricity in the endangered area. Each system stores information on sensor readings in its databases and allows access to this data at any time.

Current methanometry systems used in the mining industry are a part of integrated systems, which are called Integrated Safety Systems. They provide the following:

- continuous measurement and monitoring of methane concentration in workings and methane drainage systems, for the realization of local automated methane safety systems,

- continuous measurement and monitoring of selected air parameters, enabling early detection of underground fires,

- continuous measurement and monitoring of air parameters and its composition for ongoing analysis of ventilation conditions for undertaking the preventive measures,

- monitoring the conditions of ventilation equipment (air stoppings, main ventilation fans, auxiliary fans and ventube fans) as well as equipment and machinery for technological lines,

- monitoring of climatic conditions in underground workings and the condition of air-conditioning devices,

- location and register of employees in underground workings,

- remote control of equipment and machines,

- cooperation of systems through the automatic transmission of warning and alarm signals, 
- time synchronization in each security, communication and alarm system.

Such a system enables the following:

- implementation of the hierarchical production and safety management system adopted in the mining industry,

- operating the devices in a non-intrinsically safe version, under the condition that adequate regulations are met,

- implementation of tasks required by regulations, in particular: data visualization at the dispatching point, archiving and reporting the measurement data and events as well as control of underground power supply and signalling devices,

- automatic information of crew working in the hazardous area by generating alarm signals through signalling devices controlled by system object's outputs and/or through alarm and broadcasting systems integrated at the level of surface IT network,

- integration, at the surface IT network level, with geophysical systems for the implementation of automatic pre-emptive shutdowns of electricity in regions with a rock burst of energy that could cause a rapid methane release,

- cooperation (downloading and/or transferring data via a surface IT network) with other data acquisition and visualization systems working in mining plants.

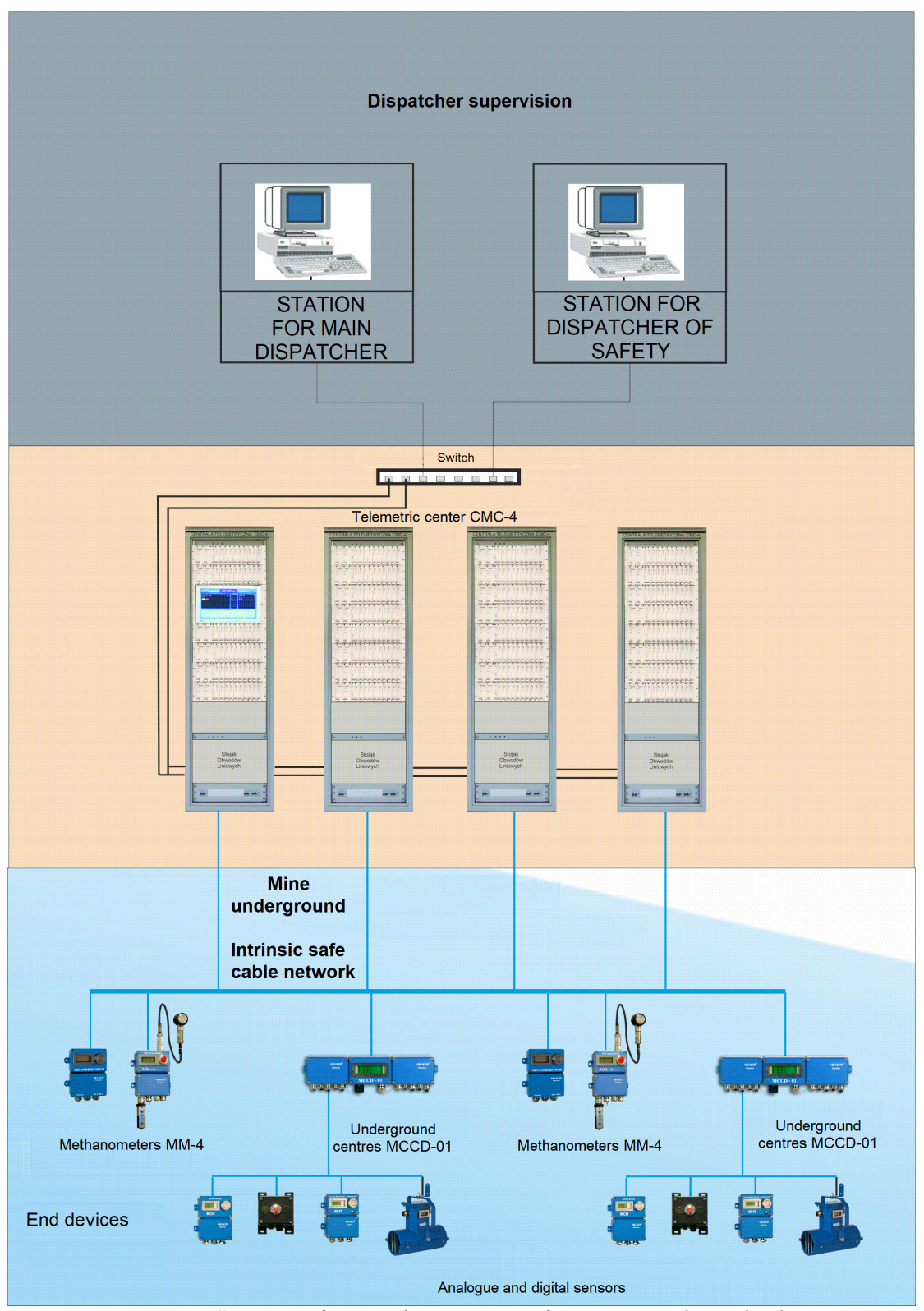

Fig. 5. Structure of a typical gasometric safety system used in Poland 
A typical gasometric system (Fig. 5) consists of the following parts:

- underground part - i.e. measuring and communication devices installed in the underground workings,

- station part - located on the surface, where telemetry systems and additional necessary communication devices are installed,

- dispatcher's part - also located on the surface, in the rooms of nominated persons, where there are computer stands with visualization software.

Such a system structure is universal in the case of all Polish coal mines. Depending on the system, the components of each part change - both quantitatively and functionally, but the overall idea remains the same.

The methane and coal dust explosion hazard in hard coal mines impose using the devices of anti-explosion manufacture intended for operation in the M1 zone at any concentration of methane in the workings. The use of such equipment allows control of the mine atmosphere as well as the condition of machinery and equipment also in the event of the electricity being turned off in the workings and the crew withdrawal from the hazardous area. Sensors and underground devices used for these purposes are divided into:

- underground concentrators, which allow data to be collected from analogue sensors (0.4-2 V signal) and binary signals, and also allow to control the operation of machines and devices through the control outputs,

- underground measuring sensors, which due to the type of output signal are divided into analoguevoltage $(0.4-2 \mathrm{~V}, 0-10 \mathrm{~V}$ ) or current $(4-20 \mathrm{~mA})$ - and digital (for example, modem in the V23 standard).

Sensors with analogue output are connected to the inputs of underground concentrators, while sensors with a digital output (for example, methane meters) are connected directly to the power supply and transmission lines from the surface.

\section{Material and Methods}

\section{Concept of improving the effectiveness of methane concentration monitoring systems in longwall panels}

Because a typical automatic methane measurement system does not allow controlling the shearer operation depending on methane concentration in the air flowing through the longwall panel, it is necessary to find another, improved method for methane monitoring. Such a method should improve the effectiveness of the existing monitoring and switching off the system in terms of safety and efficiency. That is why the concept of using an improved longwall methane measuring system was developed.

The safety aspect is associated with preventing against methane ignition in the case of a sudden outflow of methane from gobs and/or caverns - forming the methane tank in the mined coal seam - with an explosive concentration level. The concept assumes that it is possible to realize it by detecting such an outflow by a nearly located methane meter. Also, it is required that the methane meter cuts off the power supply for the machines and devices in the longwall area in a short time.

The concept of improving the effectiveness of standard automatic methane measurement consists of complementing the existing automatic methane measurement system with additional functions of the methane measuring system in the longwall panel. This will improve the detection efficiency of dangerous methane concentrations directly in the longwall as well as more rapid response of the system.

The first element of the improved longwall methane measuring system is the extension of continuous control of methane concentration in a longwall panel by installing additional methane sensors in the working itself as close as possible to the emission sources. These additional sensors should be located in the following places:

- in the near-gob zone - to control the outflow of methane from the gobs to the longwall, on a distance covering about $1 / 3$ of the length of the longwall from the side of the roadway discharging the used air, and their number would depend on the ventilation methane content of the longwall area, and it would be not less than 3 methane meters,

- in the mining zone, above the face conveyor - to control the current release of methane from the mined solid coal and transported coal, along the entire length of the longwall at a distance of about $30-50 \mathrm{~m}$ from each other, as shown in Fig. 6. 


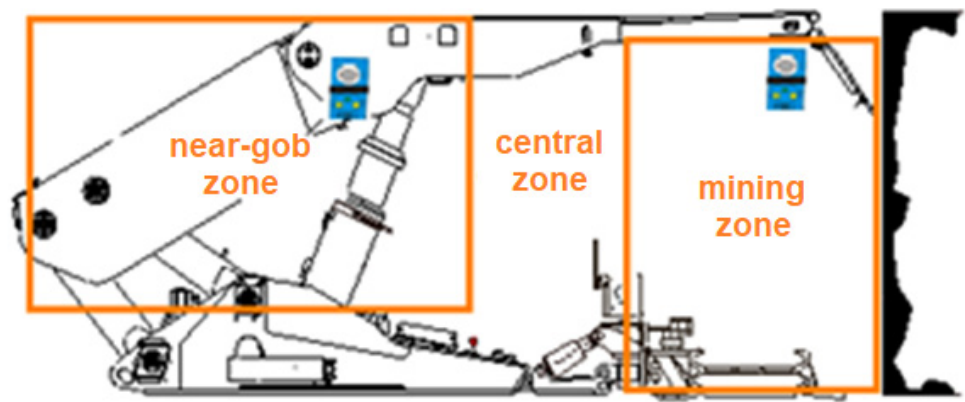

Fig. 6. An example of the location of each methane meter - an additional longwall monitoring system-in the near-gob zone and mining area

Use of short-term forecast of methane concentration in a longwall panel, especially in the area where the highest concentration is usually reported is the second part of additional methanometric system. The main objectives of such forecasting of methane concertation are as follows:

- advance indication of a possibility of exceeding the methane concentration limits,

- recommendation of slowing down or even stop of mining machines operation and eventual stop of transportation machines.

Control of the cutting process, which will use information from the methane concertation forecasting algorithm is the last element of the system. The controlling process has to use programme recommendations what would enable - depending on the forecasting information - to slow down or accelerate the operation of mining machines. This requires the development of another algorithm for controlling the operation of the shearer - AFC system. The algorithm should include the previous important aspects, i.e. operational safety and production effectiveness.

\section{Subsystem for methane monitoring in the longwall area}

Methanometric system should have a blocking function in the case of possible methane explosion. It happens, however, that methane released during coal mining flows into the longwall panel, where its concentration may exceed $2 \%$, but usually does not exceed $2.5-3.0 \%$, i.e. it does not approach the concentration equal to the bottom methane explosion limit. Then, in the case of exceeding the accepted methane concentration, the power supply for devices is cut off, and the longwall operations stop, including the run-of-mine transportation (Patra, Das, Mishra, \& Senapati, 2017). This can be achieved by slowing down the cutting advance (shearer speed), or stopping the shearer operation, while transportation equipment should still operate considering the fact that restarting the run-of-mine transportation, after it was stopped, can take up to 30 minutes (with a larger number of conveyors). After the methane concentration drops below thresholds, coal mining by a shearer can be intensified or restarted if the shearer was stopped. Such control of the shearer's operation, for economic reasons, is beneficial. Therefore, it is necessary to control the shearer's operation by the local methane concentration monitoring subsystem.

The locally operating methane monitoring subsystem in the longwall panel consists of proper sensors (Dylong, 2019) and standard power supply units, transmission system and computer hardware. Such subsystem enables measurement of methane concentrations in the longwall panel. However, the most important is the shortterm forecasting of methane concentration at the outlet from the longwall. It uses elements of the latest trends in forecasting time series (Dylong, 2019; Patra et al., 2017; Qarmalah et al., 2017; RCore et al., 2014; SanmiquelPera et al., 2019; Li et al. , 2019; Liu et al., 2006; Wu et al., 2005; Jian et al., 2008; Zhu et al., 2007).

The subsystem is characterized by:

a relatively large number of additional methane meters placed in the longwall - approx. 10-12 items,

location of methane meters in places of possible methane inflow, i.e. under the canopy of powered roof support, on a gob shield of powered roof support, on an AFC extension,

- relatively high frequency of measuring cycles - methane concentration is measured at least every $1 \mathrm{~s}$,

- $\quad$ short response time of methane measuring heads, less than $5 \mathrm{~s}(\mathrm{~T} \neg 90<5 \mathrm{~s})$,

- the power supply of the system within the longwall is based on intrinsically safe battery feeders; with the number of feeders and their locations individually matched to the needs (depending on the length of the longwall and the number of sensors),

- $\quad$ subsystem design ensuring easy integration with existing gasometric systems,

- the modular design of the subsystem enabling adaptation to local conditions.

Special attention should be paid to the location of already mentioned methane meters - they are installed on the powered roof support, and the measuring heads are placed depending on the configuration - in the gob part of 
the longwall panel, on the mining side and, if necessary, near the longwall conveyor, i.e. near the spill plate if methane is released from the floor. Installation of sensors on a longwall conveyor reduces the time required to detect dangerous concentrations of methane in the case of its presence in the near-floor part of the workings. Figure 7 shows an example of longwall with the installed sensors.

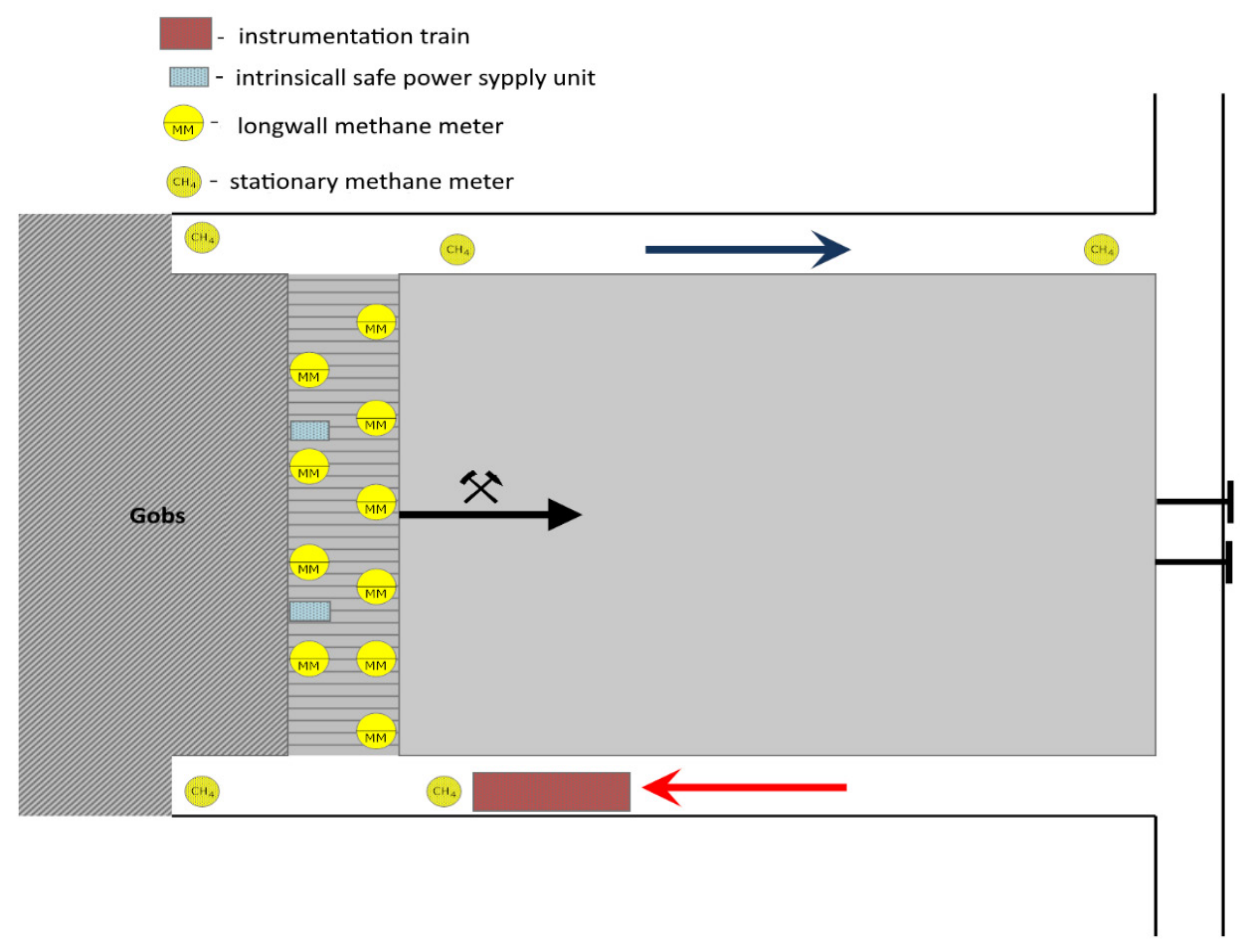

Fig. 7. Longwall panel with sensors installed on the mining and gob side

The distance between the sensors should not exceed $20 \mathrm{~m}$. In the case of using typical longwall shearers a distance from the cutterhead to the nearest sensor is from 10-12 m, regardless of the direction of the shearer's movement. In the case of movement of the shearer with the air flow maximum distance to the sensor installed in front of the shearer is $20 \mathrm{~m}$ (Fig. 8). Assuming that the air flowrate in the longwall is up to $2 \mathrm{~m} / \mathrm{s}$, a delay in gas transport to the nearest sensor is about $10 \mathrm{~s}$.

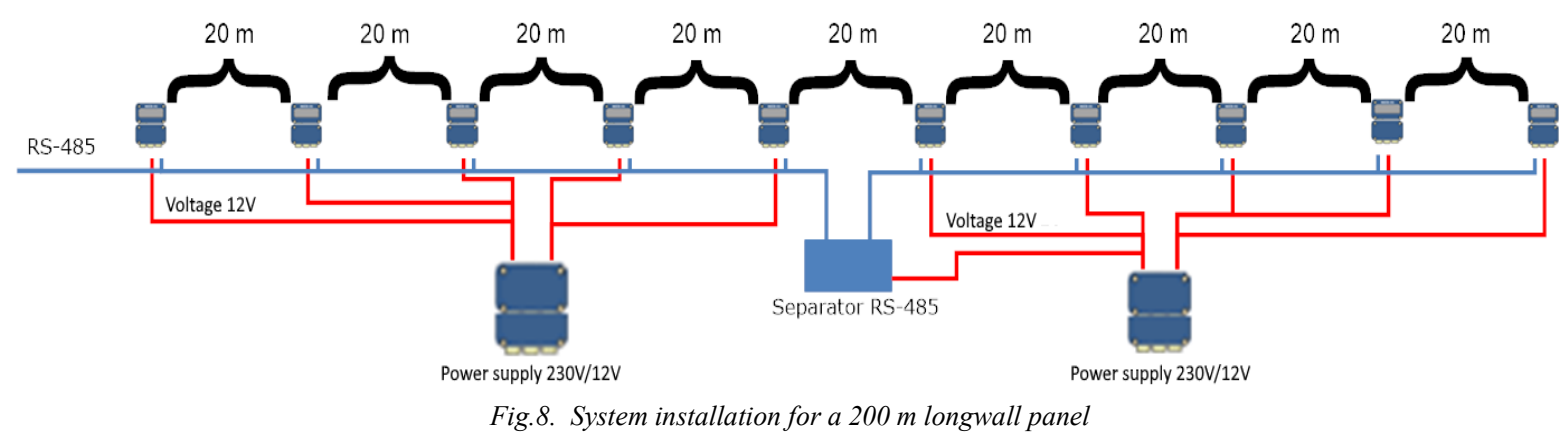

Data recorded by the sensors installed in the longwall are transmitted to the computer on the surface, where they are processed to draw conclusions. Figure 9 is a block diagram of a shearer control system with a local methane concentration monitoring system.

The forecast within a 3-minute horizon is used to develop a discrete signal that is automatically sent to the shearer without personnel intervention. Based on the signal, the shearer's control system introduces the cutting rate limit. The algorithm of the forecasting module and an example of the criteria used to define the discrete control signal is shown in Figure 10. 


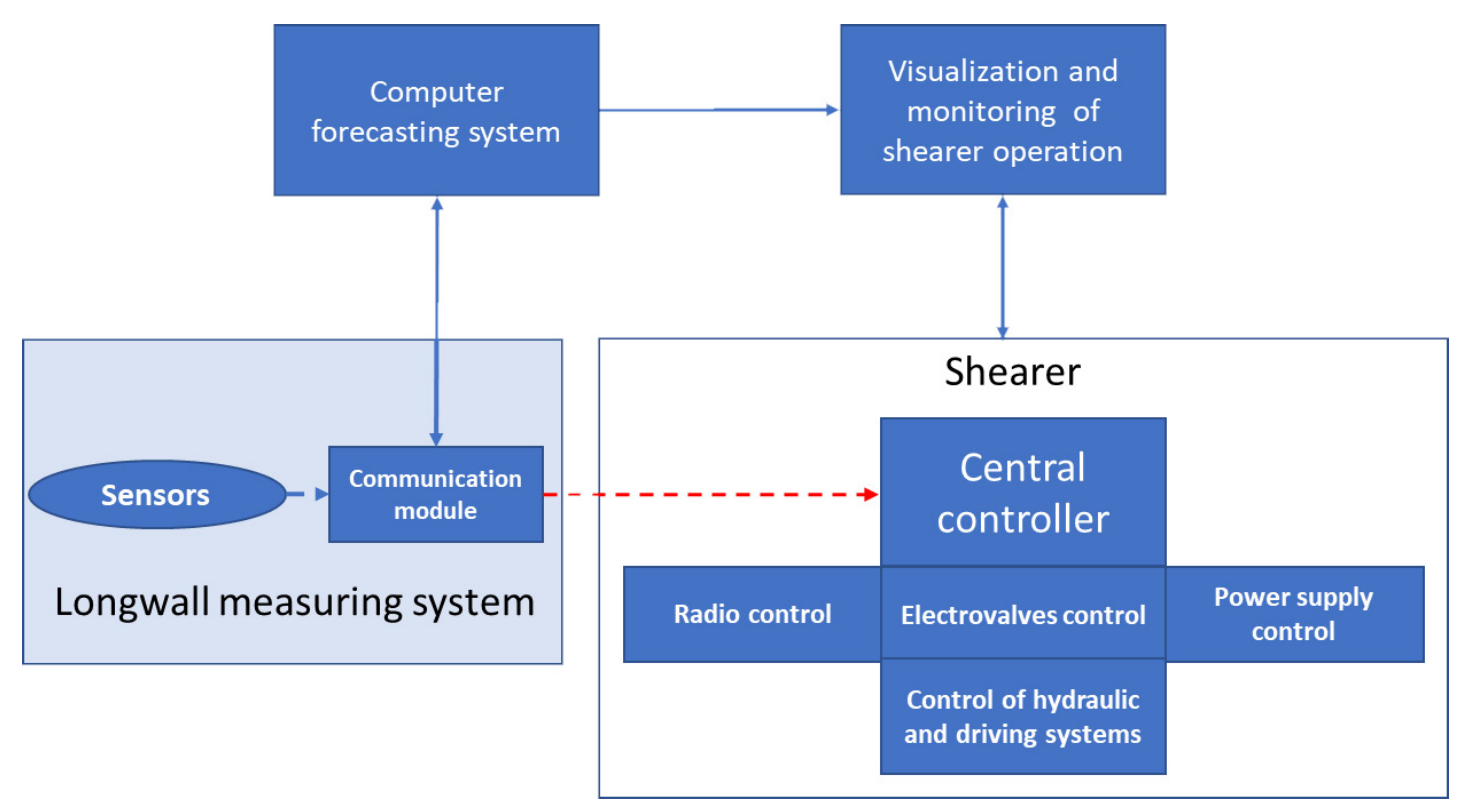

Fig. 9. Block diagram of the shearer control system with a local monitoring system (Dylong, 2019)

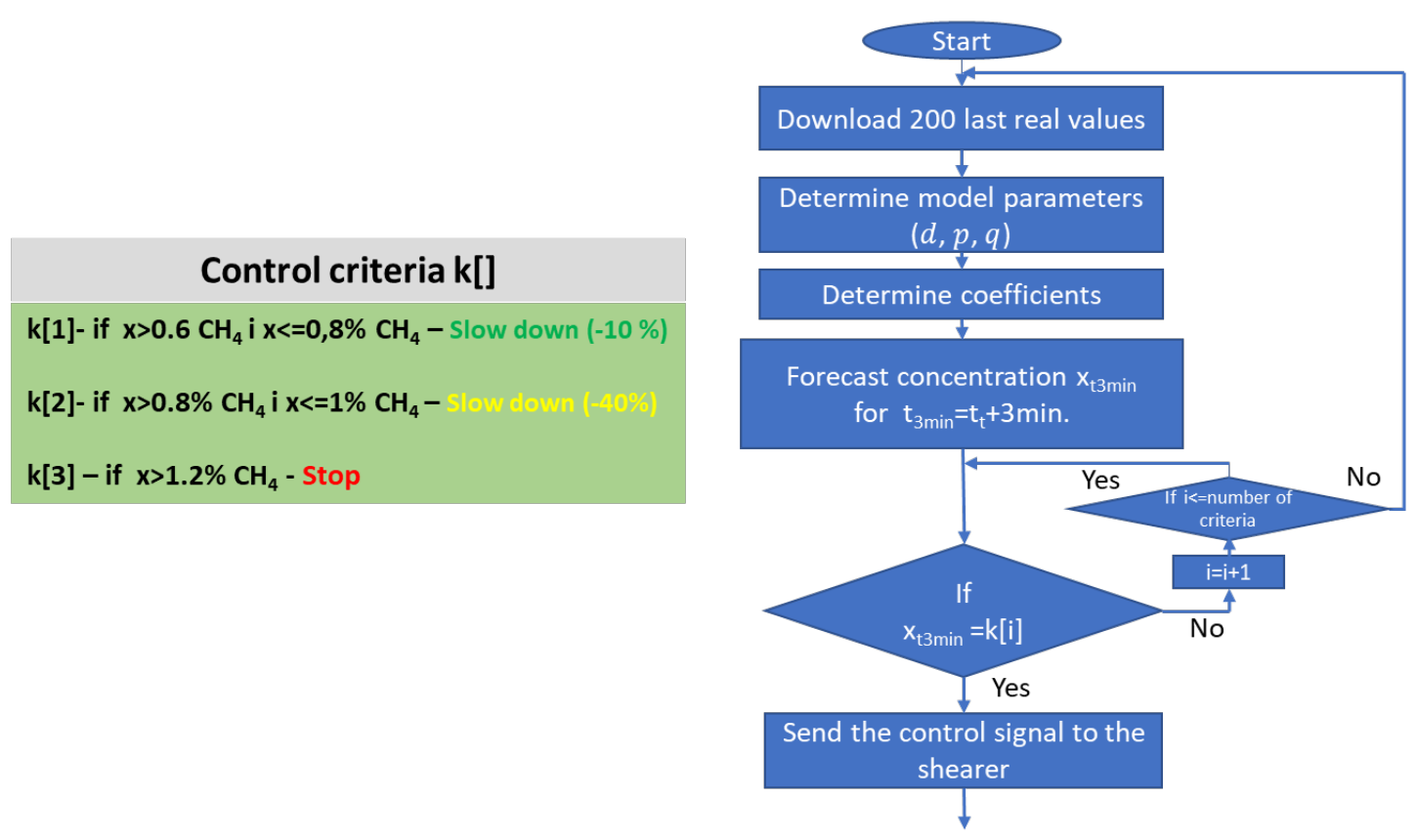

Fig. 10. The algorithm for the forecasting module operation and the defined criteria. (Dylong, 2019)

There are the following defined criteria:

- criterion 1 - when the forecast predicts the methane concentration at the outlet from the longwall in the range of $0.6-0.8 \mathrm{CH}_{4}$, a signal is sent to the shearer controller, resulting in a reduction of the cutting rate by $10 \%$,

- criterion 2 - when the forecast predicts the methane concentration at the outlet from the longwall in the range of $0.8-1.0 \mathrm{CH}_{4}$, a signal is sent to the shearer controller, resulting in a reduction of the cutting rate by $40 \%$,

- criterion 3 - when the forecast predicts the methane concentration at the outlet from the longwall in the range of $0.8-1.0 \mathrm{CH}_{4}$, a signal is sent to the shearer to stop its operation.

If the speed limiter is activated (according to the criterion), the shearer's operator receives information about the reduction in shearer speed (Baranov et al., 2017). If the forecast does not anticipate exceeding dangerous methane concentration, so none of the criterion is met, the signal about deactivating the limiter is sent to the shearer controller. Also in this case, the operator receives information about the status of the limiter.

Importantly, the criteria only apply to the operation of the shearer itself. If the shearer is stopped, the run-ofmine transportation system (longwall conveyor) continues to operate and allows transport of coal from the 
longwall panel. As we know, coal on a longwall conveyor is one of the most significant sources of methane in the longwall. This situation requires faster ventilation of the longwall panel and faster restarting the shearer and resuming the mining process.

The defined criteria are only examples. In the operating conditions, they should be selected each time when installing the system or changing the ventilation conditions.

\section{Results and discussion}

The obtained simulation results indicate that new approach to monitoring the longwall area should significantly increase the safety of mining personnel and reduce the number of downtimes of the longwall systems due to presence of methane in concentrations that make a continuation of work dangerous. Of course, using the new approach will not completely eliminate the methane hazard, but it will reduce the number of hazardous events and reduce the number of downtimes of the system. Use of a new subsystem allows for:

- measurement of methane concentration at the place of its generation,

- $\quad$ using the algorithms for short-term forecast of methane concentration based on data collected from the sensors installed in the longwall panel and at the longwall outflow,

control of the shearer operation depending on the obtained forecast of methane,

- visualization of current methane hazard in the longwall panel.

According to the mining regulations, the longwall system should be switched off when the methane concentration thresholds are exceeded. Depending on the regulation, it varies from $1.3 \% \mathrm{CH}_{4}$ to $2 \% \mathrm{CH}_{4}$.

Observations show that this action usually eliminates the possibility of a hazardous event. Stopping the longwall system reduces the amount of methane released into the longwall panel during mining. However, the coal on the longwall conveyor is an important source of methane, which, when the conveyor is stopped, increases the amount of methane in the longwall and hence the longer time is needed for ventilation. The application of the solution discussed above, enabling for forecasting the methane concentration at the longwall panel outlet allows for:

- control of methane released during mining by changing the shearer output,

- transportation of run-of-mine by AFC from the longwall panel before the methane hazard occurs and stopping the longwall system,

- reduction of time required for longwall panel ventilation and starting the longwall system again,

- monitoring the methane concentration in the longwall panel not only at its outlet.

\section{Conclusions}

In the mining process, besides the semiliquid mixture, mud, slurry, and rocks, there are large volumes of water to remove in order to keep production moving (Qazizada \& Pivarčiová, 2018; Turygin et al., 2018).

The variety of sources of methane flowing into the longwall panel in methane mines require using the methanometric systems.

The automatic methanometric system controls the methane concentration in the mine air and switches off mechanical and electrical devices in the longwall area in the case of exceeding the methane threshold concentration.

The blocking nature of the automatic methanometry allows eliminating the possibility of ignition /explosion of methane from the operation of machinery and equipment in the longwall area.

In the case of the presence of methane released during the mining process in the longwall, it is reasonable to introduce control of the longwall shearer enabling the adjustment of mining advance to the present methane concentration.

It is possible to use an additional local methane concentration monitoring subsystem in the longwall, which has the ability to cooperate with the longwall shearer control system according to algorithms for forecasting short-term methane concentration.

Controlling the shearer operation and run-of-mine transportation equipment, to reduce the number of energy shutdowns (longwall system shutdowns) caused by the accumulation of methane in the longwall panel, and slightly exceeding the thresholds, will significantly increase the work safety of mining personnel and ensure continuity of the longwall panel operation. 


\section{References}

Baranov, M., Božek, P., Prajová, V., Ivanova, T., Novokshonov, D., \& Korshunov, A. (2017). Constructing and calculating of multistage sucker rod string according to reduced stress. Acta Montanistica Slovaca. Vol. 22 (2), pp. 107-115.

Dylong, A. (2019). Prognozowanie stężenia metanu w wyrobisku ścianowym na podstawie lokalnego podsystemu sterowania kombajnem. Politechnika Śląska w Gliwicach,

Dylong, A., Knapczyk, J., \& Musioł, D. (2013). Wizualizacja bieżącego rozpływu powietrza w sieci wentylacyjnej wraz z jej monitoringiem gazowym. Górnictwo i geologia, 8(4), 5-18.

Rozporządzenie Ministra Energii z dnia 23 listopada 2016 r. w sprawie szczegółowych wymagań dotyczących prowadzenia ruchu podziemnych zakładów górniczych, (2017).

Dziurzyński, W. (2009). Badania modelowe przepływu mieszaniny powietrza i gazów w rejonie ściany w aspekcie walidacji wyników komputerowej symulacji. Przegląd Górniczy, 11-12, 61-66.

Jian, C., Jingjian, B., Jiansheng, Q., \& Shiyin, L. (2008). Short-term forecasting method of coalmine gas concentration based on chaotic time series. Journal of China university of mining \& technology, 37(2), 231-235.

Karacan, C.Ö., Esterhuizen, G.S., Schatzel, S.J., \& Diamond, W.P. (2007) Reservoir simulation-based modeling for characterizing longwall methane emissions and gob gas venthole production, International Journal of Coal Geology Volume 71, Issues 2-3, Pages 225-245

Karacan, C.Ö., \& Luxbacher, K. (2010) Stochastic modeling of gob gas venthole production performances in active and completed longwall panels of coal mines. International Journal of Coal Geology Volume 84, Issue 2, Pages 125-140

Krauze, E., \& Trenczek, S. (2019). Profilaktyka w pokładach zagrożonych zjawiskami gazogeodynamicznymi. Paper presented at the Górnicze Zagrożenia Naturalne, Jaworze.

Li, M., Lu, J., \& Xiong, S. (2019). Prediction of Fractures in Coal Seams with Multi-component Seismic Data. Scientific Reports, 9(1), 58-62.

Liu, J.-J., \& Qiao, D.-Q. (2006). Some aspects on the gas outburst/explosion hazard in coal mine of China. Journal of China coal society, 31, No. 1, 58-62.

Lutyński, A. (2010). Warunki bezpiecznej eksploatacji nowoczesnych przenośników taśmowych. Przegląd Górniczy, 12, 80-83.

Mathatho, S., Owolawi, P. A., \& Tu, C. (2019). Prediction of methane levels in underground coal mines using artificial neural networks. International Conference on Advances in Big Data, Computing and Data Communication Systems (icABCD), 1-4.

Patra, A., Das, S., Mishra, S. N., \& Senapati, M. R. (2017). An adaptive local lenear optimized radial basis functional neural network model for financial time series prediction. Neural Computing and Application, 28(1), 101-110.

Qarmalah, N., Einbeck, J., \& Coolen, F. (2017). Mixture models for mrediction from time series, with application to energy use data. Archives of data science, Series A, 2(1), 1-15.

Qazizada, M. E. \& Pivarčiová, E. (2018). Reliability of parallel and serial centrifugal pumps for dewatering in mining process. Acta Montanistica Slovaca, 23(2).

RCore, \& T.E.A.M. (2014). R: A language and environment for statistical computing. In. Internet: R Foundation for Statistical Computing, Vienna, Austria.

Sanmiquel-Pera, L., Marc Bascompta, M., \& Anticoi, H. F. (2019). Analysis of a Historical Accident in a Spanish Coal Mine. Int J Environ Res Public Health, 16(19).

Sevitel Sp. z o.o., K. (2012). Dokumentacja Techniczno-Ruchowa Systemu SMP-NT/S. In.

Szlązak, J., \& Szlązak, N. (2005). Zagrożenie metanowe w zrobach ścian zawałowych. Przegląd Górniczy, 10, 20-25.

Trenczek, S. (2015). Zapalenia i wybuchy metanu w kontekście inicjałów związanych z zagrożeniami technicznymi i naturalnymi. Przegląd Górniczy, 2, 87-92.

Trenczek, S., \& Krause, E. (2019). Wybrane zagadnienia związane z zapaleniem metanu od pracy kombajnu. Paper presented at the Górnicze Zagrożenia Naturalne, Jaworze.

Turygin, Y., Bozek, P., Abramov, I., \& Nikitin, Y. (2018). Reliability determination and diagnostics of a mechatronic system. In Advances in Science and Technology Research Journal. Vol. 12, iss. 2, s. 274-290.

Wu, A.-Y., Tian, Y.-L., Song, Y., \& He, L.-W. (2005). Application of the grey system theory for predicting the amount of mine gas emission in coal mine. Journal of China coal society, 30(5), 489-592.

Zhu, H.-Q., Chang, W.-J., \& Zhang, B. (2007). Different-source gas emission prediction model of working face based on BP artificial neural network and its application. Journal of China coal society, 32(5), 504-508.

Zmarzły M. \& Trzaskalik P. (2019). Comparative analysis of methane concentration near the junction of the longwall and top road. Management Systems in Production Engineering, Volume 27, Issue 3, p-ISSN 22990461, e-ISSN 2450-5781. pp. 166-173. DOI: 10.1515/mspe-2019-0027. 